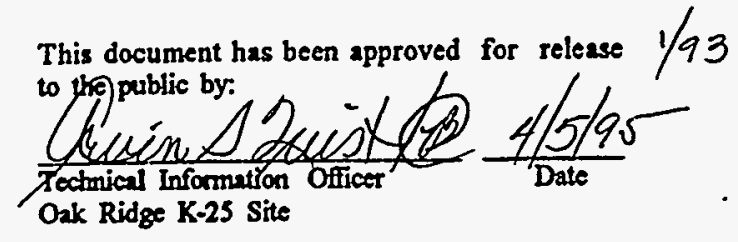

K/TCD-1057

\title{
PRELIMINARY INVESTIGATION OF STEEL COMPATIBILITY WITH POTENTIAL MATERIALS OF CONSTRUCTION FOR UF6 CYLINDER CHOCKS
}

\author{
S. J. Pawel \\ K. T. Ziehlke \\ C. J. Swindeman
}

December 1992

Prepared by the

Technical Division

Oak Ridge K-25 Site

Oak Ridge, Tennessee 37831-7101

managed by

MARTIN MARIETTA ENERGY SYSTEMS, INC.

for the

U.S. DEPARTMENT OF ENERGY

under Contract DE-AC05-84OR21400 


\section{DISCLAIMER}

This report was prepared as an account of work. sponsored by an agency of the United States Government. Neither the United States Government nor any agency thereof, nor any of their employees, makes any warranty, express or implied, or assumes any legal liability or responsibility for the accuracy, completeness, or usefulness of any information, apparatus, product, or process disclosed, or represents that its use would not infringe privately owned rights. Reference herein to any specific commercial product, process, or service by trade name, trademark, manufacturer, or otherwise, does not necessarily constitute or imply its endorsement, recommendation, or favoring by the United States Government or any agency thereof. The views and opinions of authors expressed herein do not necessarily state or reflect those of the United States Government or any agency thereof. 


\section{DISCLAIMER}

Portions of this document may be illegible in electronic image products. Images are produced from the best available original document. 


\section{EXECUTIVE SUMMARY}

A set of compatibility experiments was performed to assess corrosion susceptibility of mild steel in long term contact with $\mathrm{UF}_{6}$ cylinder chocking materials and the atmosphere. Chock materials considered included concrete, pressure-treated wood, and creosote-treated wood. Immersion tests (panels partially submerged, $1000 \mathrm{~h}, 38^{\circ} \mathrm{C}$ ), resistance probe measurements ( $600 \mathrm{~h}$, ambient), and cyclic polarization tests on steel in leachate solutions generated from each chock material were performed. Results indicate that the long term corrosion susceptibility of mild steel in contact with concrete and the atmosphere is at least the equivalent of-and under some conditions superior to-that for steel in contact with pressure-treated or creosote-treated wood. No corrosion-related limitation for concrete chocks for long term support of mild steel $\mathrm{UF}_{6}$ cylinders was identified. 


\section{INTRODUCTION}

Isotopically depleted $\mathrm{UF}_{6}$ has been stored in 48-in. diam steel cylinders since the early 1950s. In the early years, the cylinders were stored on a space-available basis, but as numbers and space requirements increased, the storage arrangements became more formal with dedicated areas (storage yards) being set aside in the 1960s. Contoured wooden chocks were used initially to stabilize cylinder placements; the wood was creosote-treated to improve weathering resistance. With evidence of chock deterioration in the 1970s, Paducah personnel designed and procured concrete chocks for use on gravel yard surfaces while continuing use of wooden chocks on concrete surfaces. The Portsmouth site (with only concrete storage surfaces for $\mathrm{UF}_{6}$ cylinders) and the Oak Ridge K-25 Site (both concrete and compacted gravel storage yard surfaces) have historically used only wooden chocks.

At the K-25 Site, cylinders were moved from K-1066G to K-1066K in 1982 for several reasons. Subsidence problems (asphalt-paved parking lot was not designed to support heavy $\mathrm{UF}_{6}$ cylinders) and potential corrosion problems such as ground contact and pitting (a few observations but not specifically characterized) in the saddle contact areas of some cylinders were the main driving forces to move the cylinders. Some observations of cylinder pitting near the chock supports were again noted in 1990 surveys of the K-25 Site storage yards, and limited observations of accelerated attack in the wood saddle area have also been reported at Paducah.

Recent chock procurements have been for pressure-treated wood because creosote is no longer considered environmentally acceptable. Further, a recent decision by the U. S. Department of Energy mandates all future chock procurements shall be for concrete construction. Over the past 15 years or so, experience with concrete chocks at Paducah has not indicated any evidence of accelerated steel corrosion due to contact with concrete. There is, however, no formal test data to support the observations of Paducah personnel regarding absence of concrete-related cylinder corrosion nor is there any data regarding corrosion of cylinders associated with wooden-chocks. The lack of compatibility data and the readiness of Portsmouth Site personnel to reorder chocks in 1992 provide the impetus for the present series of tests. 


\section{EXPERIMENTAL APPROACH}

Due to deadlines imposed by the planning and decision-making processes, time for data collection in this investigation was limited to about two months. As a result, the test program included factors designed to significantly accelerate the nominal corrosion expected as a result of steel contact with candidate chock materials and atmospheric moisture (rain, dew).

The major premise of the accelerated tests chosen is that, if steel corrosion is a strong function of chock material, it is likely to be associated with water soluble constituents of the chock material collecting in moisture and accelerating corrosion reactions. Therefore, test solutions were generated by soaking candidate chock materials (creosote-treated wood, pressure-treated wood, and concrete) in demineralized water for about $48 \mathrm{~h}$. To accelerate leaching tendency, the surface area of the chock materials was increased substantially by splintering the wood specimens and pulverizing a concrete specimen obtained from a Paducah chock; the soak temperature was about $38^{\circ} \mathrm{C}$ rather than ambient. At ambient temperature, the leachate so developed from the pulverized concrete was found to be clear with a $\mathrm{pH}$ near 12. The leachate from the pressure-treated wood was observed to be dark brown with a $\mathrm{pH}$ of 5-6 and that for the creosote-treated wood was light golden brown at a pH near 4. No formal composition analysis was performed for the leachate solutions.

For the immersion tests, panels of prototypic steel (ASTM A516) ${ }^{1}$ of dimensions $10 \times 4 \times 0.75 \mathrm{~cm}$ were cut from plate used in UF6 cylinder production. Panels with three different surface finishes (polished by grinding on 180-grit paper, polished and oxidized in an air furnace, and glass-bead-blasted) were partially immersed in leachate solutions for about $1000 \mathrm{~h}$ at $38^{\circ} \mathrm{C}$. Each panel was positioned about one-half immersed with the long dimension parallel to the solution surface. Duplicate glass-bead-blasted panels were exposed in each leachate solution and triplicate panels were exposed for the other surface conditions.

Electrical resistance probe tests were also conducted over approximately one month. A 0.20-mm tubular loop and a 2.0-mm wire loop-both polished mild steel-were exposed to the leachate solutions at room temperature. Daily changes in electrical resistance were monitored and converted to a general corrosion rate averaged over the entire specimen.

In addition, standard cyclic polarization tests were performed for mild steel in each leachate solution at room temperature. The purpose of these tests was to estimate susceptibility to localized corrosion and compare corrosion characteristics of steel in the leachate solutions over a wide potential range.

\footnotetext{
${ }^{1}$ Test coupons were cut from a scrap cylinder involved in another test program. This cylinder, S.N.130437, was a model G storage cylinder fabricated from ASTM A516 steel by Modern Welding Co., of Owensboro, Kentucky, in 1983.
} 


\section{RESULTS AND DISCUSSION}

\subsection{IMMERSION TESTS}

In general, the steel panels exhibited an irregular distribution of orange, red, and black corrosion products following the $1000-\mathrm{h}$ immersion at $38^{\circ} \mathrm{C}$. These corrosion products were not analytically identified, but they are normal for steel in aqueous environments and are no doubt typical oxides and hydroxides of iron. Almost without exception, the greatest accumulation of corrosion products was observed at, or just below, the solution interface. Representative photographs appear in Figs. 3.1-3.3.

To estimate an average corrosion rate based on weight loss of the panels during exposure, it was necessary to chemically remove the corrosion products from each specimen. This was performed in accordance with the guidelines of ASTM G-1 (1990) with a solution of $100-\mathrm{ml} \mathrm{HCl}+5-\mathrm{g}$ stannous chloride $+2-\mathrm{g}$ antimony trichloride at room temperature with vigorous agitation. Typically, $>95 \%$ of the corrosion product was removed in a matter of seconds and no significant steel corrosion occurred as a result of this cleaning procedure.

Average corrosion rates for each steel panel were calculated based on the cumulative weight loss and total exposure time of the specimen. This measurement revealed very little scatter among the multiple panels exposed for each condition and the average corrosion rate for each surface preparation and leachate solution appears in Table 3.1.

Table 3.1. Average corrosion rate (mils/year) for steel panels as a function of surface finish and leachate solution Calculations assume panel weight loss uniformly distributed and of uniform intensity

\begin{tabular}{|c|c|c|c|}
\hline- & $\begin{array}{l}\text { concrete } \\
\text { leachate }\end{array}$ & $\begin{array}{c}\text { pressure-treated } \\
\text { wood leachate }\end{array}$ & $\begin{array}{l}\text { creosote-treated } \\
\text { wood leachate }\end{array}$ \\
\hline polished & 2.9 & 4.6 & 4.6 \\
\hline oxidized & 1.7 & 3.3 & 5.4 \\
\hline glass-bead & 5.6 & 5.2 & 5.8 \\
\hline
\end{tabular}

In general, the data in Table 3.1 predict that steel corrosion resistance increases as a function of surface preparation in the order of glass-bead-blasted, polished, and polished and oxidized panels. This increase in resistance may be related to a general decrease in surface area of steel susceptible to corrosion, with the oxidized surface being somewhat "passivated" prior to immersion in the leachates. Further, corrosion rates are generally lowest in the concrete leachate and highest in the creosote leachate. Certainly, the $\mathrm{pH}$ of the leachate solutions contributes in large measure to this lowering of $\mathrm{pH}$, and the alkaline $\mathrm{pH}$ of the concrete leachate tends to minimize steel corrosion. Based on data collected at room temperature, it is suspected that the $\mathrm{pH}$ of each leachate drifts slowly toward neutral with extended time in contact with air. Such behavior would minimize the magnitude of differences in corrosion rate based solely on $\mathrm{pH}$. 


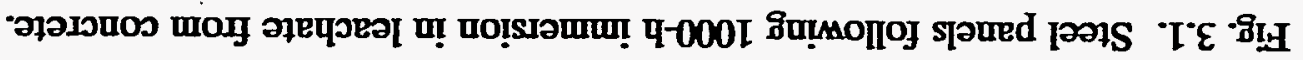
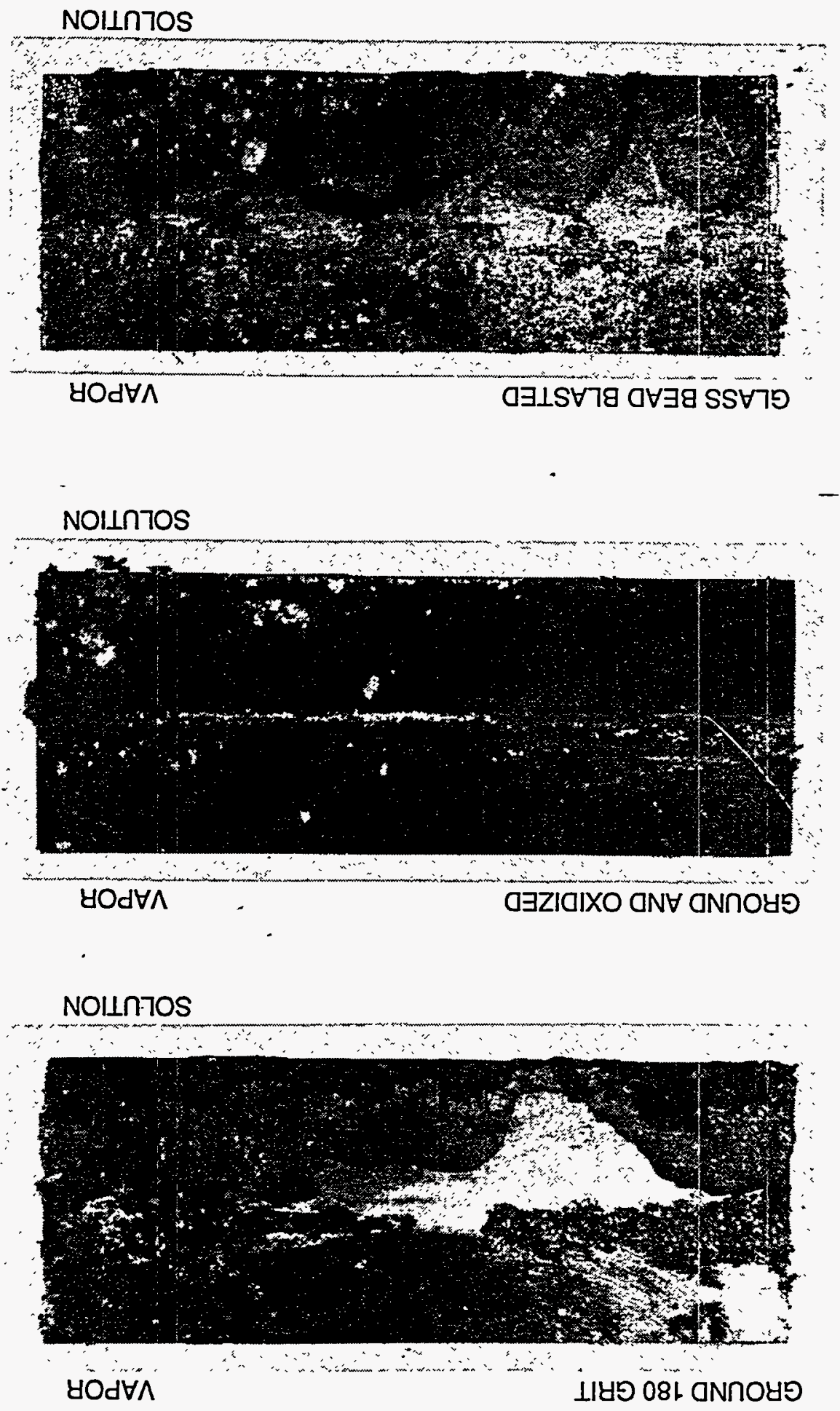
a.

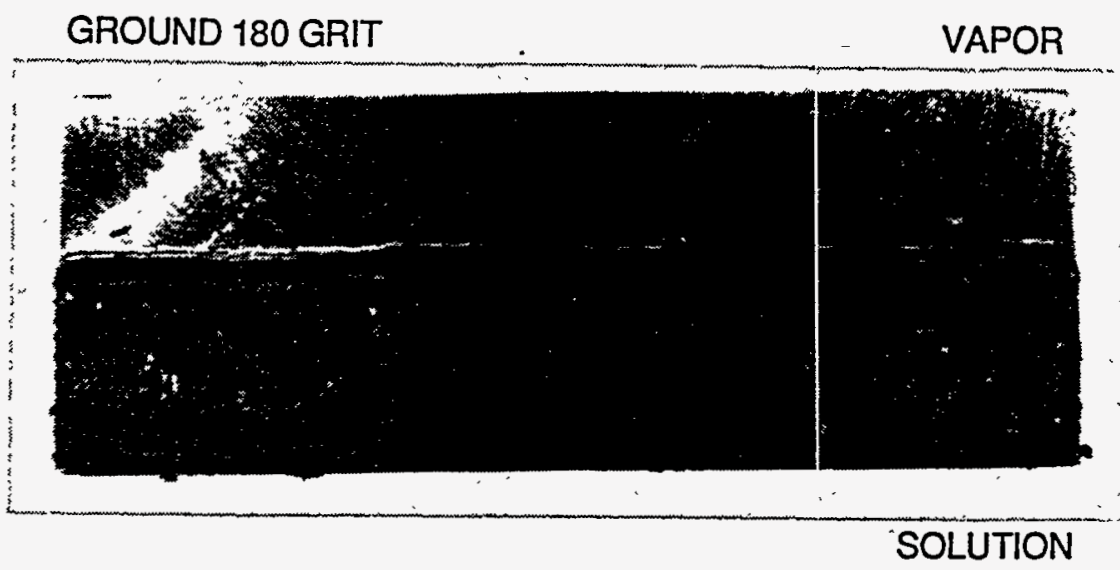

b.

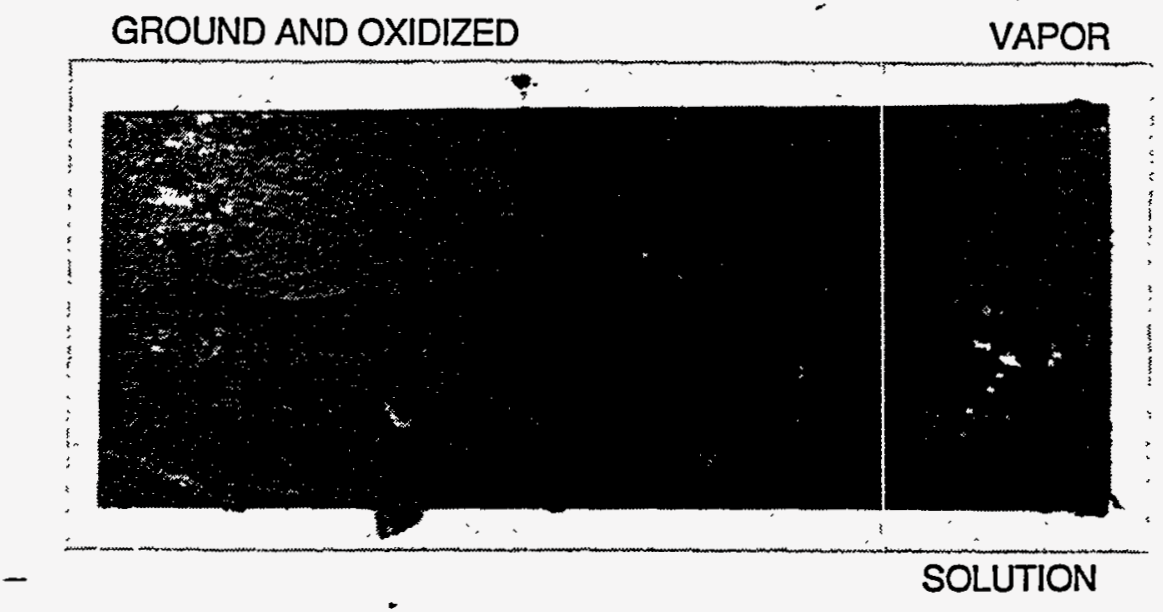

c.

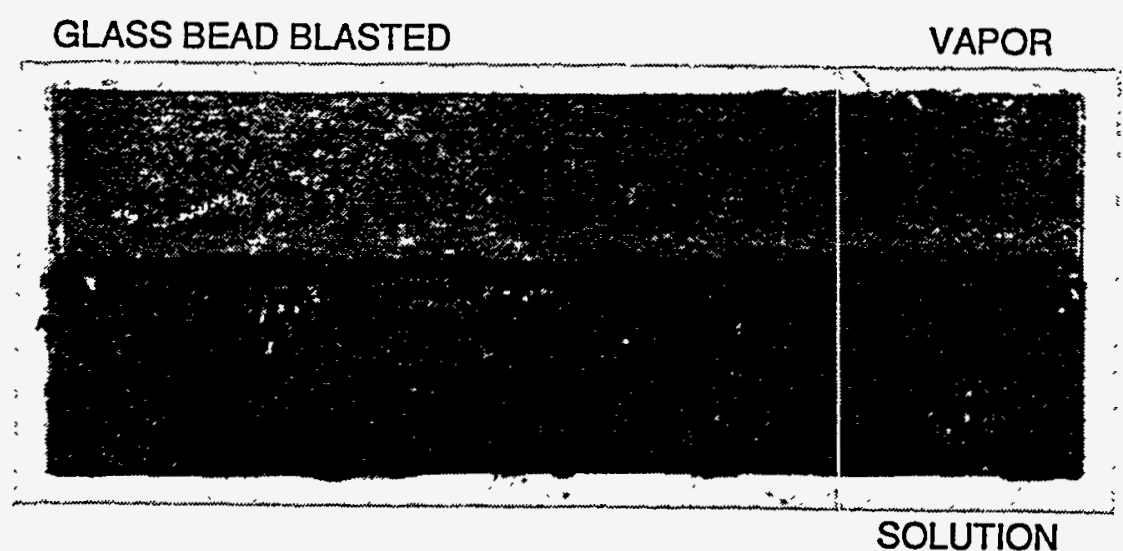

Fig. 3.2. Steel panels following 1000-h immersion in leachate from pressure-treated wood. 
a.

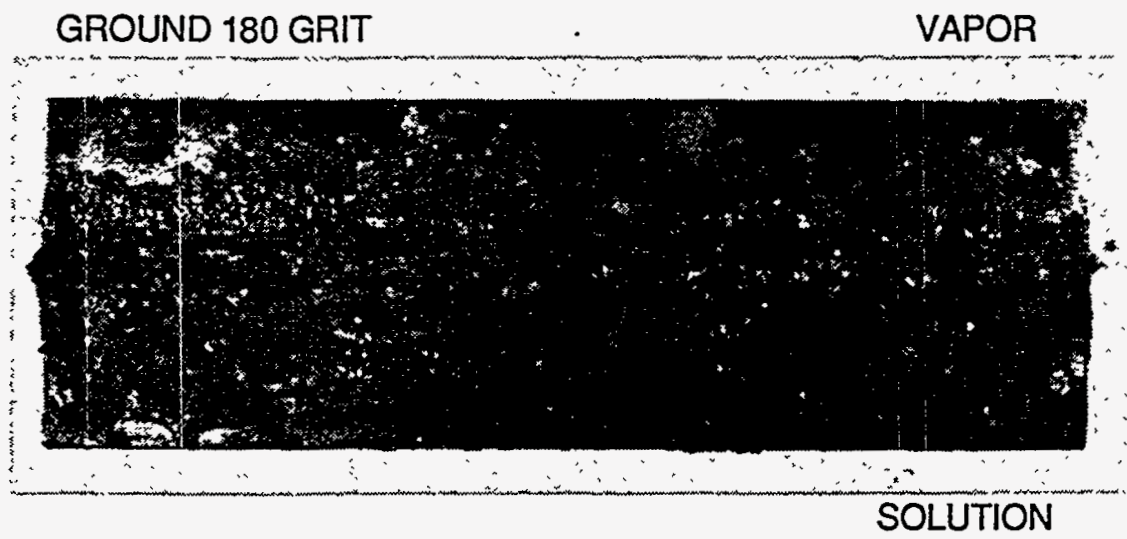

b.

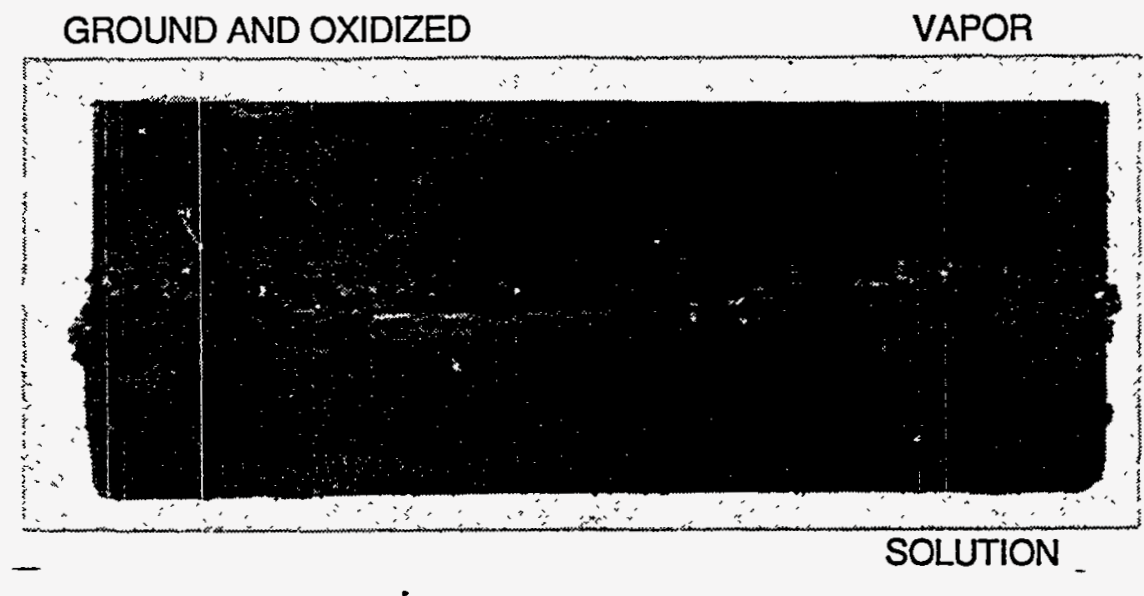

c.

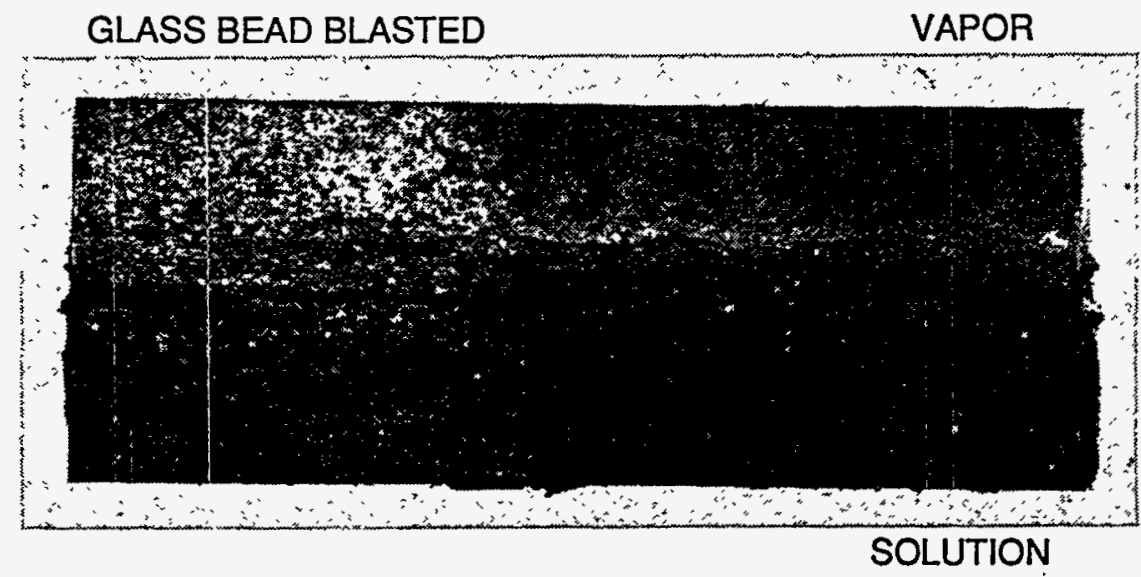

Fig. 33. Steel panels following 1000-h immersion in leachate from creosote-treated wood. 
Following removal of corrosion products from the corroded panels, each was examined for signs of localized attack. In general, no pits were observed, and the regions of increased surface roughness (typically under heavy corrosion product accumulation) were estimated to be no more than $0.125 \mathrm{~mm}$ ( 5 mils) deep. One interesting exception was observed: local attack adjacent to the ID stamp on a panel exposed in concrete leachate (oxidized surface condition) on the order of $0.75 \mathrm{~mm}$ deep. This attack was only noted on a single coupon and is considered at present to be an unusual artifact rather than an indication of susceptibility to localized attack inherent to concrete leachate solution. Representative photographs of specimens following removal of corrosion products appear in Figs. 3.4-3.6.

Following the leachate exposures, test coupons were sectioned for metallographic assessment of the nature and degree of corrosive attack. The sections were taken across the solution line so that both immersed and moist air surfaces could be examined.

The coupons showed qualitatively similar degrees of attack, which was primarily of a localized nature. Shallow, closely spaced "pits" formed at the surface and during the exposure duration bridged together giving the appearance (at least below the solution line) of general corrosion and a roughened surface. Atmospheric corrosion observed in the field is of a similar nature, except that the "pits" are much more widely spaced and the surface does not appear to roughen dramatically as corrosion advances. Corrosion in high time-of-wetness regions such as the wood/chock areas may result in increased "pit" density ard rapid connection of adjacent depressions resulting in surface roughening below the accumulated corrosion product. Representative photomicrographs of sections through glass-bead-blasted coupons are shown in Figs. 3.7 and 3.8.

\subsection{ELECTRICAL RESISTANCE PROBE TESTS}

Solutions for testing were taken from the same lot of leachates prepared for the immersion tests. In this test, the daily $\mathrm{pH}$ of each solution was monitored and found to drift slowly toward neutral over a period of a few days. The magnitude of the change was most significant for the concrete leachate as the $\mathrm{pH}$ drifted from near 12 to near 8 over a period of a few days. As a result, the test solutions were replaced with fresh solution after $4 \mathrm{~d}$. Although the $\mathrm{pH}$ was again observed to drift slowly, no subsequent solution changes were performed.

Table 3.2 contains resistance probe data from this investigation. With the exception of a slightly increasing corrosion rate due to the drop in $\mathrm{pH}$ in the concrete leachate, the resistance probe data indicates that the average corrosion rate with time is essentially constant in each environment. The tiny diameter tube is known to be a rnuch more sensitive measuring element than a relatively thick wire, and the corrosion rates are greater in each case for the tube. At present, the huge magnitude of the difference between tube and wire corrosion rates in the creosote leachate is not understood; however, the magnitude of attack on the tube specimen was readily confirmed visually after the test. 
a.

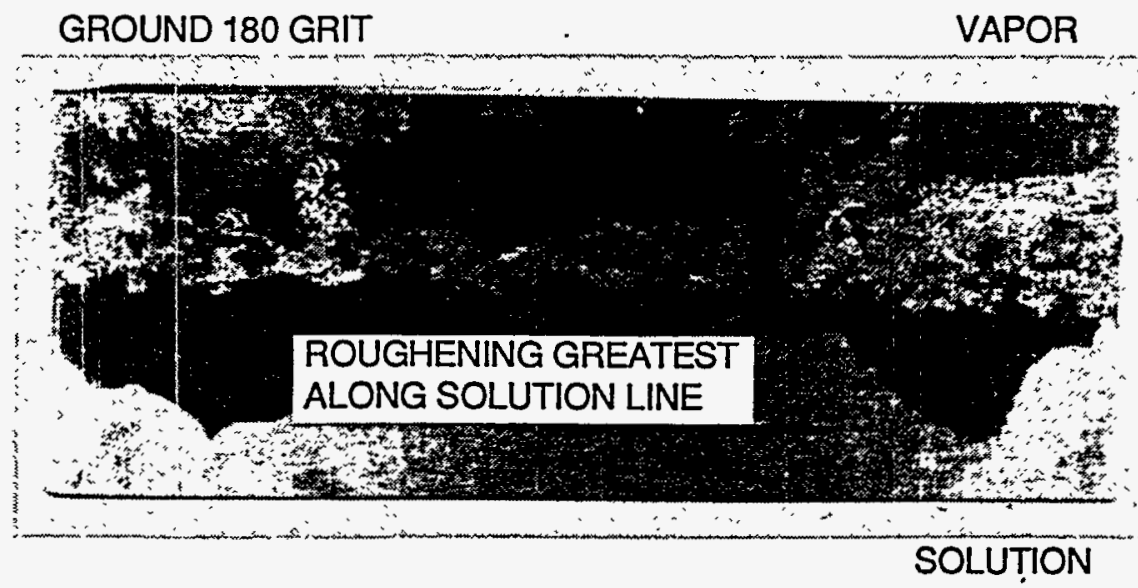

b.

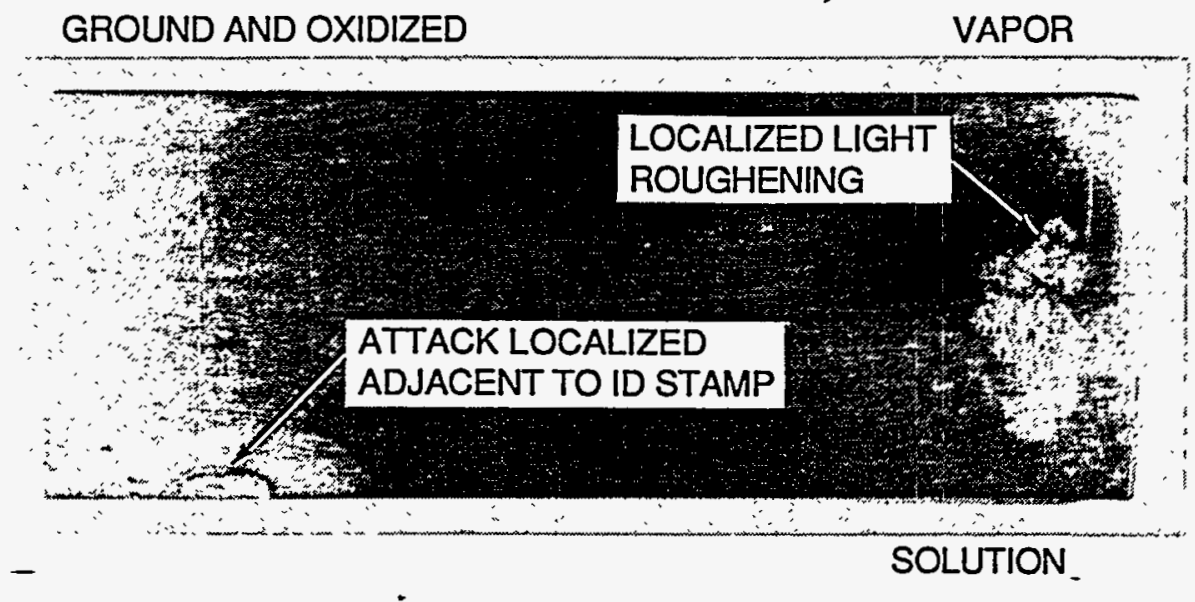

c.

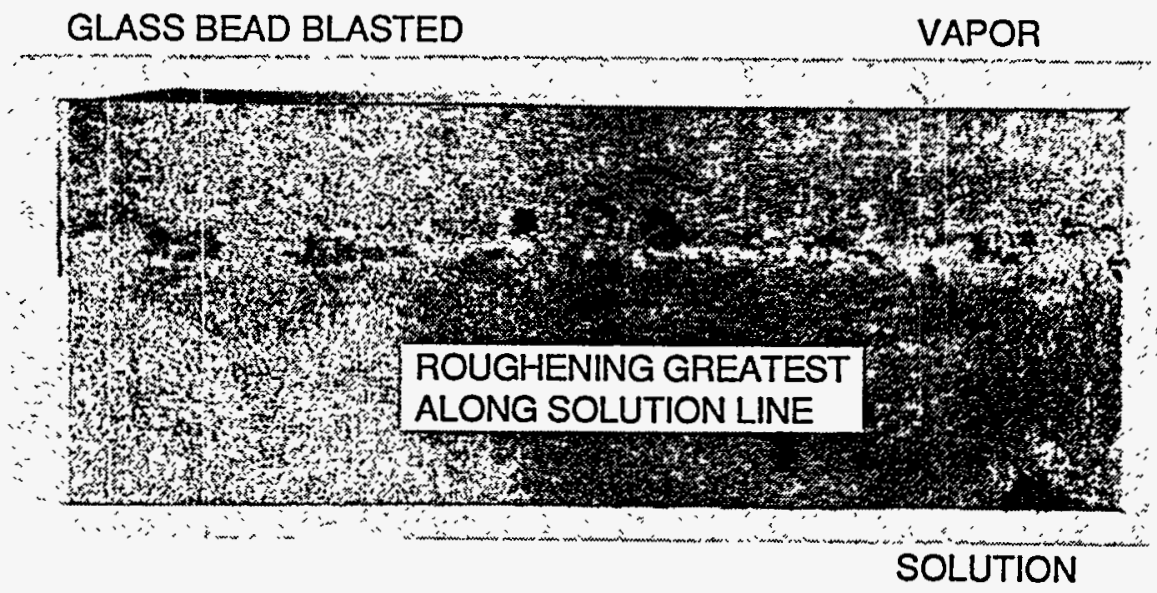

Fig. 3.4. Steel panels following 1000-h immersion in leachate from concrete and removal of corrosion products. 
a.

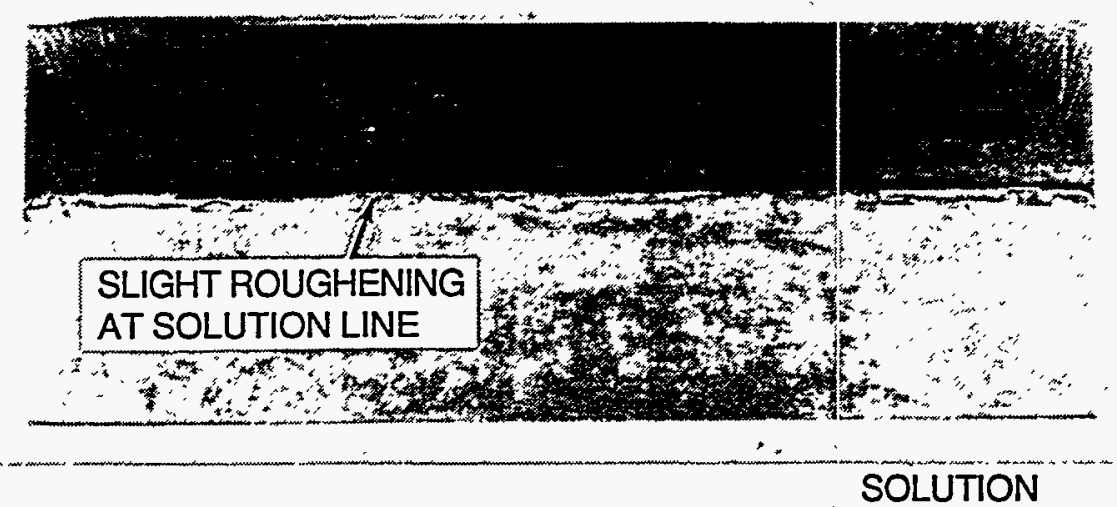

b.

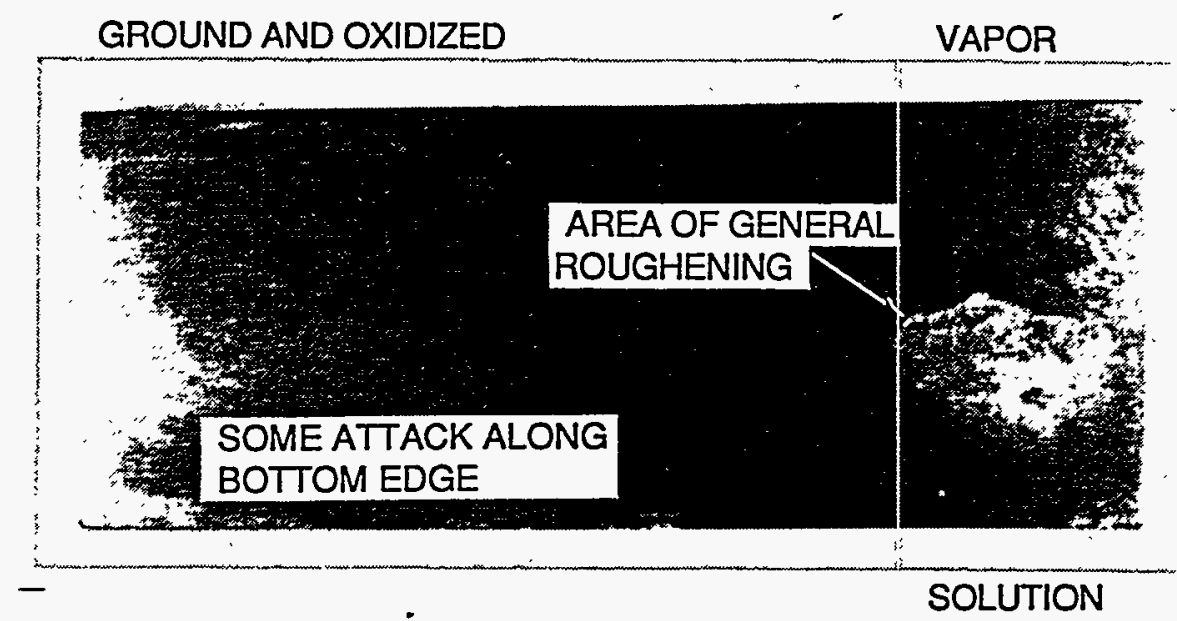

c.

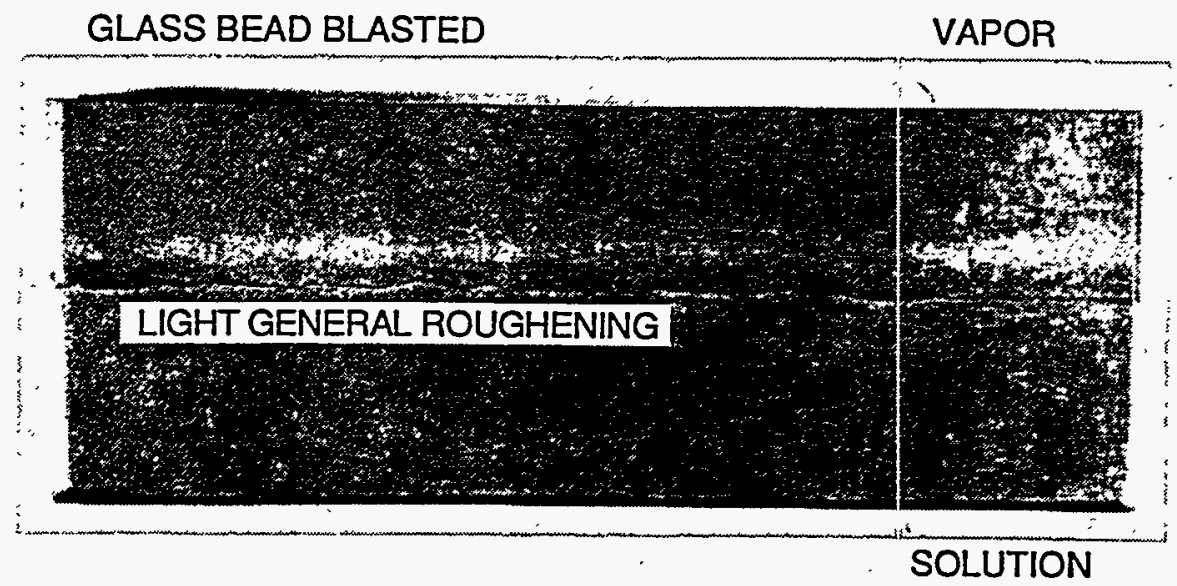

Fig. 3.5. Steel panels following $1000-\mathrm{h}$ immersion in leachate from pressure-treated wood and removal of corrosion products. 
'stonpoid uoisouros jo jesoməI

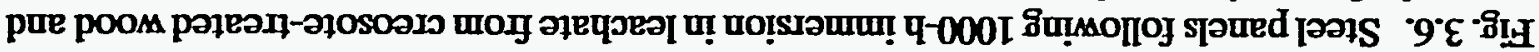
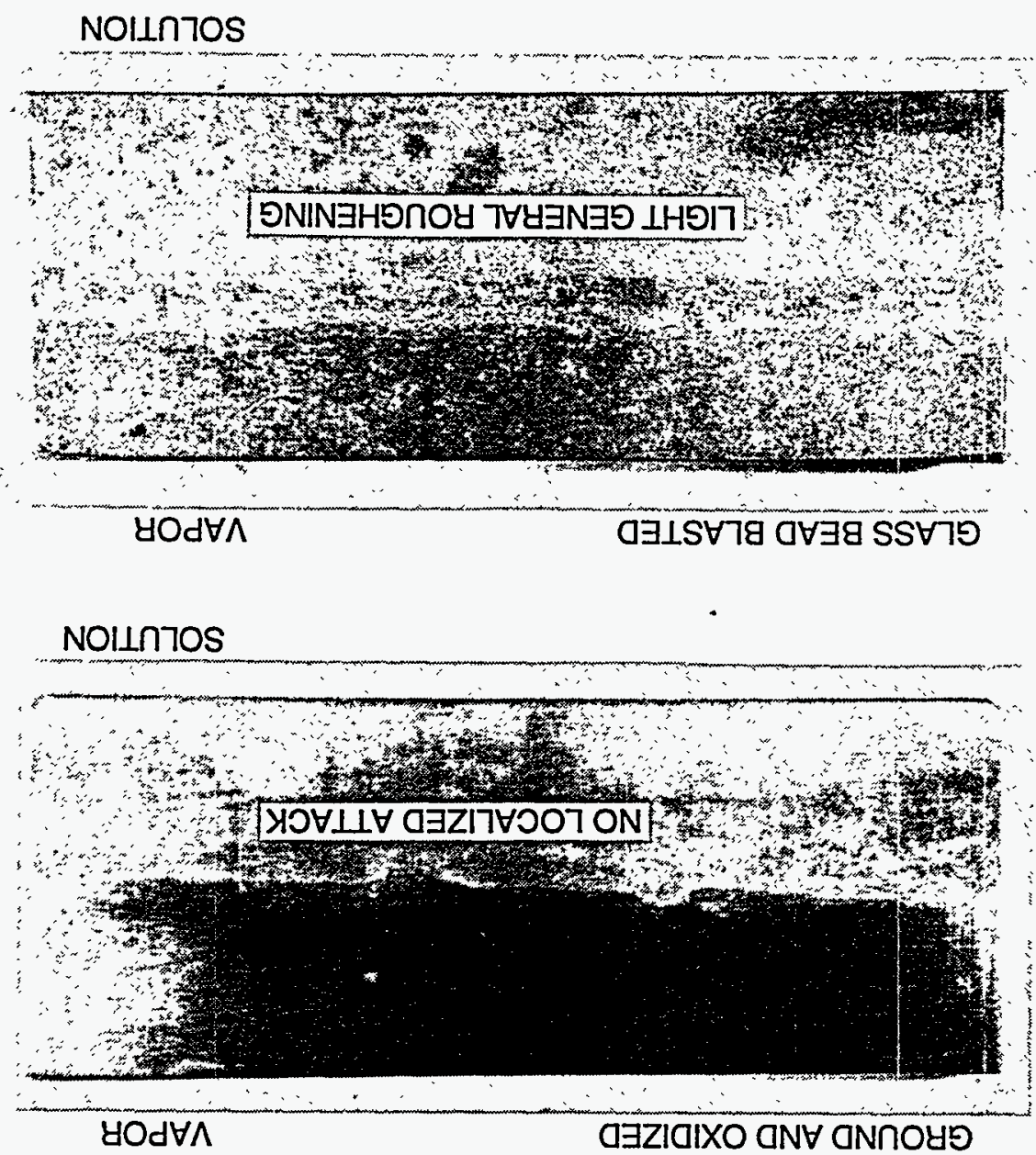

NOIกากS

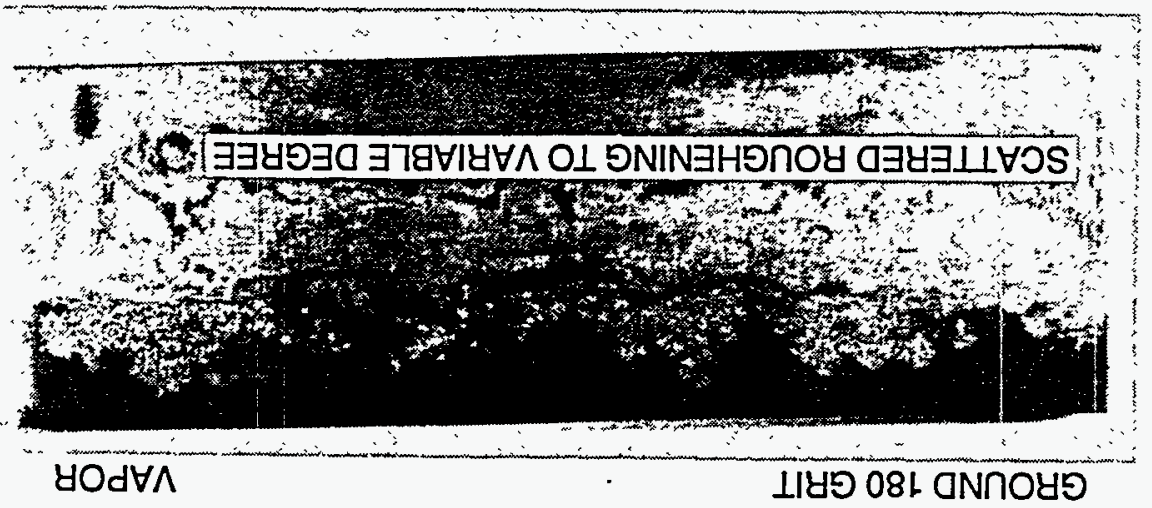


a. Below

liquid

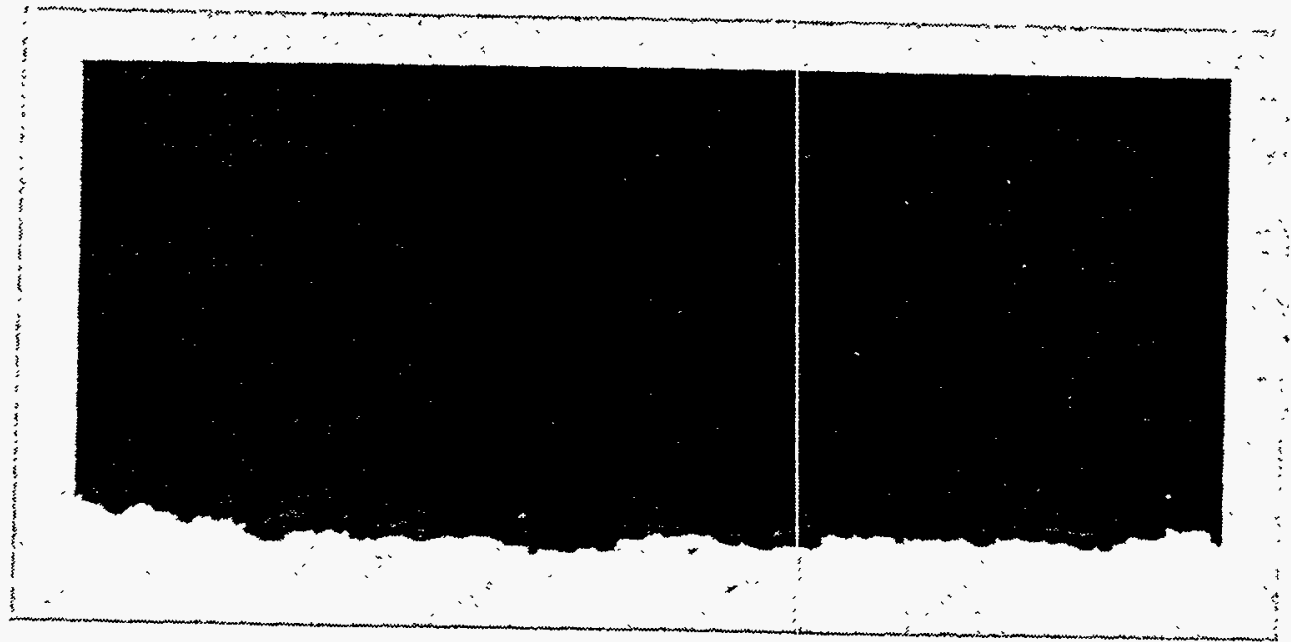

b. Across

liquid

level

line

Fig. 3.7. Glass-bead-blasted surfaces in creosote/wood leachate. 
a. Below

liquid

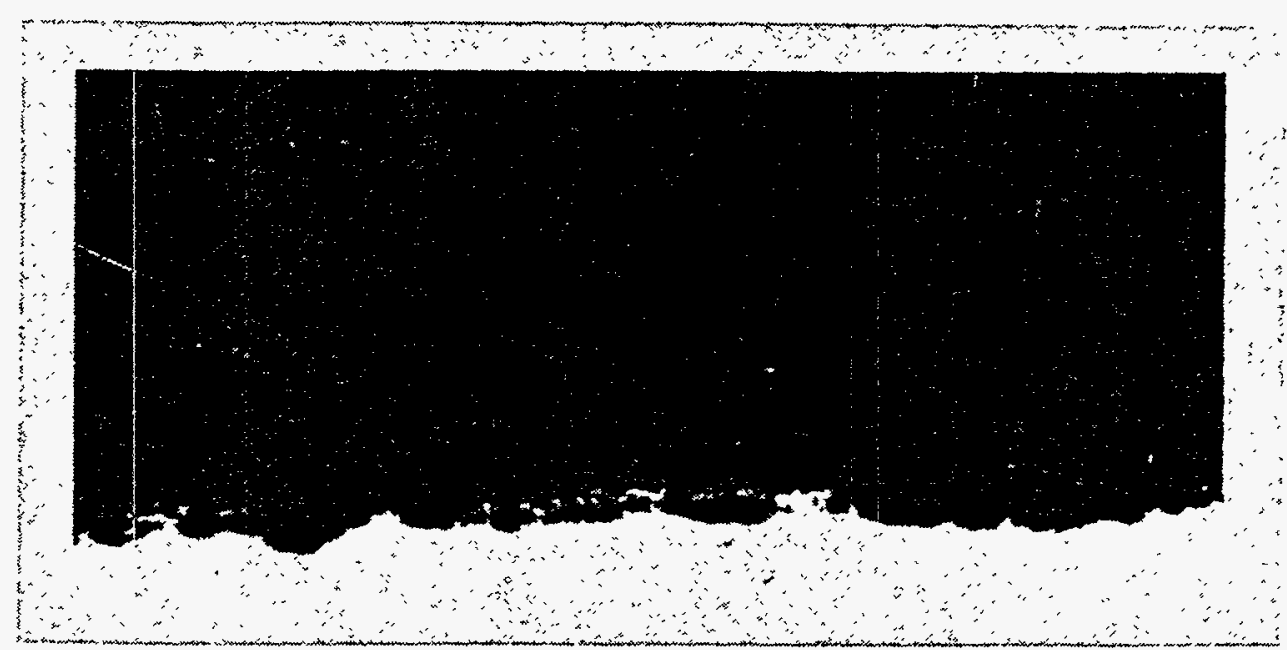

b. Across

liquid

level

line

$-$

Fig. 3.8. Glass-bead-blasted surfaces in concrete leachate. 
Table. 3.2 Corrosion rate summary (milsfyear) for mild steel resistance probes exposed to chock material leachates Average corrosion rate over the full $25 \mathrm{~d}$ and over the final half of test given for each probe configuration

\begin{tabular}{ccccccc}
\hline & \multicolumn{2}{c}{$\begin{array}{c}\text { concrete } \\
\text { leachate }\end{array}$} & \multicolumn{2}{c}{$\begin{array}{c}\text { pressure-treated } \\
\text { wood leachate }\end{array}$} & \multicolumn{2}{c}{$\begin{array}{c}\text { creosote-treated } \\
\text { wood leachate }\end{array}$} \\
\cline { 2 - 8 } & tube & wire & tube & wire & tube & wire \\
\hline overall & 6 & 2 & 4 & 3 & 52 & 8 \\
last half & 10 & 4 & 4 & 3 & 52 & 4 \\
\hline & & & & & & \\
3.3 & CYCLIC POLARIZATION TESTS & & & & &
\end{tabular}

Polished (600-grit) type 1010 steel specimens, similar in composition to the cylinder steels, were utilized for this phase of the investigation. Leachate from the same batch of solutions previously prepared were used at room temperature with no deliberate attempt to aerate or deaerate the solutions during testing. After a 1-h irnmersion to establish a stable open circuit potential $\left(E_{c}\right)$, the potential upscan was initiated at $E_{c}-300 \mathrm{mv}$ at a rate of $0.6 \mathrm{v} / \mathrm{h}$. The upscan was continued to $E_{c}+1200 \mathrm{mv}$ and then the scan direction was reversed and returned to the starting potential. The polarization curves were then examined for indications of susceptibility to localized corrosion (principally, current instabilities and hysteresis during downscan). Table 3.3 contains summary data taken from the polarization curves for each leachate solution.

Only a single polarization scan was performed for each leachate (primarily due to heavy accumulation of steel corrosion products in the wood leachate solutions with no fresh solution available). Consistent with the $\mathrm{pH}$ of each leachate, steel corrosion at open circuit potential is more than an order of magnitude lower in concrete leachate than the pressure-treated wood leachate and almost two orders of magnitude lower than in the creosote-treated wood leachate. Further, the polarization scan in concrete leachate indicated stable passivity at low current density (order of $2 E-06 \mathrm{amp} / \mathrm{cm}^{2}$ ) to $E_{c}+900 \mathrm{mv}$. At $E_{c}+900 \mathrm{mv}$, the scan indicates a well-defined departure from stable passivity. Failure of the curve to "retrace" itself during the downscan from the maximum potential after the departure from passivity indicates localized corrosion rather than an electrochemical reaction in the solution; some indication of accelerated corrosion at the edges of the sample was confirmed after the test. The scans in wood leachates indicated marginal passivity (order of $3 E-104$ to $3 E-03 \mathrm{amp} / \mathrm{cm}^{2}$ ) along with some current instability. The curves in wood leachate did not yield a well-defined indication of localized corrosion near the peak potential, but each exhibited a sudden increase in current during the downscan from maximum potential that is further indication of marginal passivity in the range $E_{c}$ to $E_{c}+600 \mathrm{mv}$. 
Table 3.3 Summary of data and observations from cyclic polarization curves for type 1010 steel in chock material leachate solutions

\begin{tabular}{|c|c|c|c|}
\hline & $\begin{array}{l}\text { concrete } \\
\text { leachate }\end{array}$ & $\begin{array}{l}\text { pressure-treated } \\
\text { wood leachate }\end{array}$ & $\begin{array}{l}\text { creosote-treated } \\
\text { wood leachate }\end{array}$ \\
\hline solution $\mathrm{pH}$ & 12.3 & 5.6 & 3.9 \\
\hline $\begin{array}{l}\text { open circuit } \\
\text { potential, mv } \\
\text { versus SHE }\end{array}$ & -288 & -544 & -610 \\
\hline $\begin{array}{l}\text { open circuit } \\
\text { current, } \\
\text { amp/cm }\end{array}$ & $2.7 E-07$ & $6.3 \mathrm{E}-05$ & $2.0 \mathrm{E}-04$ \\
\hline $\begin{array}{l}\text { corrosion rate } \\
\text { at open circuit } \\
\text { (mils/year) }\end{array}$ & 0.1 & $29^{\circ}$ & 91 \\
\hline $\begin{array}{l}\text { upscan passive } \\
\text { current } \\
\text { character }\end{array}$ & $\begin{array}{l}\text { low, stable to } \\
E_{c}+900 \mathrm{mv}\end{array}$ & $\begin{array}{l}\text { high, } \\
\text { instable }\end{array}$ & high \\
\hline
\end{tabular}




\section{SUMMARY AND RECOMMENDATION}

A set of compatibility experiments was performed to assess corrosion susceptibility of mild steel in long-term contact with $\mathrm{UF}_{6}$ cylinder chocking materials and the atmosphere. Chock materials considered included concrete, pressure-treated wood, and creosote-treated wood and test solutions were generated by soaking splintered wood or pulverized concrete in demineralized water for $48 \mathrm{~h}$ at $38^{\circ} \mathrm{C}$. Accelerated immersion tests (panels partially immersed, $1000 \mathrm{~h}, 38^{\circ} \mathrm{C}$ ) indicated typical corrosion products and moderate general corrosion rates (average of 2-6 mils/year) for steel in each solution with only scattered roughening to depths near $0.125 \mathrm{~mm}$. While not a large factor, the steel corrosion rates generally increased in the order of concrete, pressure-treated wood, and creosote-treated wood leachate for each steel surface finish. Resistance probe measurements at ambient temperature in the leachate solutions again confirmed moderate corrosion rates, with those in concrete and pressuretreated wood leachate being similar and somewhat lower than for steel in creosote-treated wood leachate. Cyclic polarization measurements were perforned for steel in each leachate solution, and stable passivity with much lower corrosion rate was found for the steel in concrete leachate compared to the wood leachates.

As a result of this investigation, it may be concluded that mild steels in contact with concrete and exposed to ambient outdoor conditions will not corrode more rapidly-and may well corrode less rapidly - than mild steels in contact with pressure-treated or creosote-treated wood. No corrosion-related limitation for concrete chocks for long-term support of mild steel $\mathrm{UF}_{6}$ cylinders was identified, and it is therefore concluded that concrete chocks are appropriate for this service. 


\section{ACKNOWLEDGEMENTS}

The authors gratefully recognize the contributions of many individuals to this document. H. M. Henson organized the investigation team, and H. E. Philpot procured representative chock materials. R. R. Steele and G. C. Marsh performed and monitored the immersion tests. J. M. Chapman performed and monitored the resistance probe measurements. R. T. Grandey assisted with the cyclic polarization measurements. 


\section{DISTRIBUTION}

DOE Oak Ridge Field Office

R. J. Spence (2)

Oak Ridge K-25 Site

W. D. Altman

C. R. Barlow

J. T. Bradbury, III

H. M. Henson

R. K. Kibbe

D. L. Mason

V. S. Newman

G. A. Person

H. E. Philpot

F. W. Stout

M. S. Taylor

D. L. Weishaar

K. T. Ziehlke (3)

Oak Ridge Y-12 Site

W. G. Northcutt, Jr./A. M. Ammons

S. J. Pawel (3)

C. J. Swindeman (3)

Paducah Site

J. H. Alderson

S. C. Blue

E. E. Brown

C. D. Ecklund

W. G. Halicks

Portsmouth Site

R. A. Boelens

M. E. Conkel

G. D. Davidson

R. E. Dorning

J. M. Hortel 